\title{
SERVICE QUALITY BASED ANALYSIS : CASE OF HOUSEKEEPING ATTENDANT, SEGARA VILLAGE HOTEL
}

\author{
Ni Made Ayu Sulasmini, I Gede Gio Pana Saputra \\ STPBI
}

\begin{abstract}
Quality of service is any activity carried out by the company or hotel in order to meet consumer expectations. The dimensions of the service quality are Tangible, Reliability, Responsiveness, Assurance and Empathy. Various efforts need to be considered by the hotel in order to satisfy the guests. So is the case with Segara Village Hotel which is a four-star hotel in Sanur. This study aims to determine the quality of service of room attendants at Segara Village Hotel, using the techniques of qualitative-quantitative descriptive analysis. Respondents in this study were guests at Segara Village Hotel as many as 50 people. Data obtained by questionnaires that measured using a Likert scale. Data were analyzed using analysis techniques and performance level of importance, and the Cartesian diagram. It was found that the factors are a top priority (considered important by guests, but the implementation is felt still less) is the appearance of room attendant, accuracy, reliability, timeliness in cleaning room, the provision of information to the guests, room attendant accuracy, and understanding of what is desired by guests.
\end{abstract}

Keywords: Quality of Service, Dimension of Service Quality

\section{Introduction}

Tourism is the travel activities undertaken by tourists temporarily from original places to destinations with reasons not to settle or make a living but merely to satisfy curiosity, spending free time or holidays as well as other purposes (Koen Meyers: 2009 ).

With complete tourism facilities and services, including the availability of hotels and services, Bali will make the tourists who have visited to make a return visit. Guest satisfaction rate can be determined by comparing the quality of service received by guests during a guest's stay at the hotel in the hope that is expected to be met with a service received by guests.

As it happens in Segara Village located area of Sanur. Because the level of guest satisfaction is very important, then the hotel is trying to improve the quality of service in all departments, especially in maid or housekeeping department.

Maid or housekeeping department is one of the departments that is directly related to guests within its operations. Based on some guest comments or guest reviews on the website or internet site there are guest comments who have stayed at Segara Village Hotel on room service provided to guests felt not meet the expectations of guests. So based on it this study conducted on service quality of 
housekeeping attendants at Segara Village Hotel, entitled "Analysis of Service Quality of Housekeeping attendants at Segara Village Hotel".

\section{Research Question} Hotel?"

"How is the quality of service of housekeeping attendant at Segara Village

\section{Scope of the Research}

This study is limited to housekeeping attendant services related to service quality dimensions (SERVQUAL). The dimensions are: reliability, responsiveness, assurance, empathy, and direct evidence (tangible).

\section{Literature Review}

Rahmawati Herlina's research on Analysis of Service Quality Using SERVQUAL Method and IMPORTANCE PERFORMANCE ANALYSIS in the Office of Library and Archives at Karang Anyar regency showed that library services at the Library and Archives Office of Karanganyar not satisfy the users or the quality of service has not met the users' expectations.

Ni Wayan Nila Lestari in her Butler Service Quality Analysis In Increasing Guest Satisfaction at Santika Premiere Beach Resort Bali conducted qualitative descriptive data analysis techniques using SERVQUAL method concluded that Butler service quality has not reached expectations of guests and has not been able to increase guest satisfaction to the maximum.

\section{Definition of Services}

According to Kotler in Laksana (2008) service is any action or activity that can be offered by one party to another, which is essentially intangible and does not result in any ownership. While Gronroos in Tjiptono (2005) states that the service is a process that consists of a series of activities intangible commonly (but not always) occurs in the interaction between customers and employees, services and resources, physical or goods, and system service providers, provided as the solution to the customer's problem.

\section{Understanding Quality of Service}

Quality of service is any activity carried out by the company in order to meet consumer's expectations.

From Parasuraman research (1990) there are 10 general dimensions of Quality of Service

1. Tangibles, is the appearance of physical, equipment, personnel and communication tools.

2. Reliability, is the ability to provide correct services that have been promised. 
3. Responsiveness, namely a willingness to assist service users by providing appropriate services.

4. Competence, is the knowledge and skills necessary to provide services.

5. Courtesy, that is the respect, courtesy and hospitality given during delivering service.

6. Credibility, is a trust given to service providers.

7. Security, which is a sense of freedom from danger, risk or doubt.

8. Access, is the ease to be reached and contacted.

9. Communication, is the ease of communicating with service users, including a willingness to listen to complaints and wishes of service users.

10. Understanding the customer, which is an effort to understand the needs and wishes of service users.

Based on the concept of quality of service and 10 dimensions of assessment above, then Parasuraman (1990) developed a measurement tool to measure the quality of service is referred to as "servqual". In the servqual tool, 7 last dimensions are classified into two broader dimensions which are assurance and empathy, so that the dimensions in servqual are simplified to:

1. Tangibles: Physical appearance, equipment, personnel, communication materials.

2. Reliability: the ability to carry out the service that has been promised to accurately and reliably.

3. Responsiveness: the ability to help service users and provide fast service.

4. Assurance: knowledge and courtesy of employees and their ability to earn the trust of service users.

5. Empathy: the attitude of care, individual attention given by the company to service users.

\section{Customer Satisfaction}

Customer satisfaction is the level of one's feelings after comparing the performance of the product that one felt with one's expectations. Satisfaction is achieved when the quality meets and exceeds the expectations, desires and needs of consumers. Conversely, if the quality does not meet and exceed the expectations, desires and needs of consumers, the satisfaction is not achieved. Guests ort customers' satisfaction is achieved when the quality of housekeeping attendant service at Segara Village Hotel meets and exceeds expectations, wants and needs of customers or guests staying at Segara Village Hotel. 


\section{Methodology}

The type of research used by the writer is descriptive quantitative research. Samples were taken from 50 people staying here.

\section{Operational Definition of Vriables}

\section{Service Quality}

Quality of service is any activity carried out by the company in order to meet consumer expectations. This study examined the dimensions of service quality including:

a. Tangible (physical evidence)

Indicators in this dimension is housekeeping attendant appearance, cleanliness of guest rooms, guest rooms and facilities arrangement and completeness of guest amenities and guest supplies.

b. Reliability

The indicators in this dimension are the precision in serving guests, service as promised, housekeeping attendant reliability, and timeliness in cleaning the guest rooms.

c. Responsiveness

Indicators in this dimension that is housekeeping attendants provide information desired by the guests, the speed of housekeeping attendants in helping guests, housekeeping attendants' willingness to help the guests, and serve meticulously.

d. Assurance (guarantee)

The indicators in this dimension is that guests feel safe when served, housekeeping attendants' courteous attitude, the ability to maintain guests' comfort, and provide the right solution at the time of a complaint.

e. Empathy

The indicators in this dimension are housekeeping attendants' communication skills, the ability to listen to the guests' wishes, understands the guests' needs, and provide personal attention.

\section{Data analysis technique}

To answer the problem formulation regarding the extent to which quality of service housekeeping attendant at Segara Village Hotel, ImportancePerformance Analysis (John A. Martila and John C. James, 1997: 77-79) is used. The level of conformity is the result of the comparison a score of performance or quality of service with interests score. The level of conformity will determine the order of priority of improving the factors that affect customer satisfaction.

Customer satisfaction can be analyzed from two dimensions, namely the expectation of something and the reality that the consumer received. Because of it, matters in question will consist of two dimensions. Data from the questionnaire values plotted on Cartesian diagram. It is to see the fit between customer perceptions and expectations. When you are in quadrant $\mathrm{A}, \mathrm{B}, \mathrm{C}$ or $\mathrm{D}$, then the each component in question will have their meanings, as described below: 


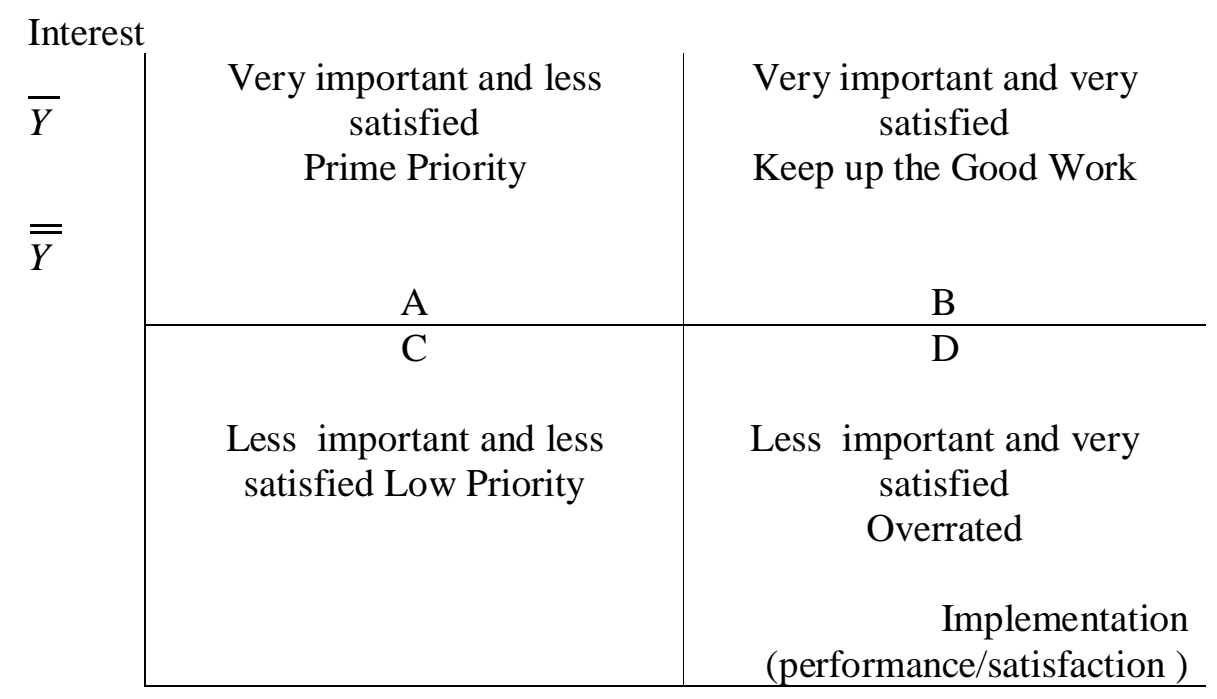

Findings

Figure 3.2

Cartesian Diagram

Factors and variables which become top priority because it was considered important by customers or guests, but its implementation is still less and should be implemented in accordance with the expectations of customers or guests staying at Segara Village Hotel are:

a. Housekeeping attendants' appearance when serving guests staying at Segara Village Hotel.

b. Housekeeping attendants' accuracy in serving guests staying at Segara Village Hotel.

c. Housekeeping attendants' reliability in serving guests staying at Segara Village Hotel.

d. Housekeeping attendants' timeliness in cleaning the guest rooms.

e. Housekeeping attendants can provide information desired by the guest.

f. Housekeeping attendants serve the guests carefully.

g. Housekeeping attendants understand the needs desired by the guest.

h. Reliability variable or reliability.

1. Factors and variables that need to be maintained for implementation or performance, since its implementation was appropriate and meets the expectations of customers or guests staying at Segara Village Hotel. The factors and variables are:

a. The cleanliness of guest rooms for guests staying at the Segara Village Hotel.

b. Guests feel safe when served by Housekeeping attendant.

c. Housekeeping attendants' politeness in serving guests. 
d. Housekeeping attendant capability in providing the right solution to guest complaints.

e. Housekeeping attendants' ability to communicate with guests.

f. Tangible variable or physical evidence.

2. Factors considered less important by customers, but its implementation has been done fairly by the Housekeeping attendant at Segara Village Hotel are:

a. The services provided are in accordance with the promise of Segara Village Hotel.

b. Housekeeping attendant serve guests meticulously.

c. Variable responsiveness or responsiveness.

3. Factors of implementation or performance were done very well by housekeeping attendants, but considered less important by customers, so it seemed excessive. In this case, the factors that are considered redundant are:

a. Room facilities are neat and attractive.

b. Facilities provided are complete and well maintained.

c. Housekeeping attendants' speed in helping guests.

d. Housekeeping attendant willingness to assist guests.

e. Hou sekeeping attendants' ability in maintaining the guests' comfort.

f. Housekeeping attendants' capability in providing the right solution to guest complaints.

g. Housekeeping attendants' ability to communicate with guests.

h. Housekeeping attendants' ability to listen to guest's wishes.

i. Housekeeping attendants can give personal attention to guests.

j. Tangible variable or physical evidence.

$\mathrm{k}$. Assurance variable or guarantee.

1. Empathy variable or empathy.

\section{References}

Agusnawar. Operational (2000). Tata Graha Hotel. (http://www.adbpolnes03.blogspot.com/2006/09/aktivitas-penangananroom-linen-ajeng.html?m=1).

Amir, Taufiq. (2005). Dynamics of Marketing Browse and Feel. Jakarta: PT. King Grafindo

Persada.

Housekeeping Bagyono. (2009).Manajemen Hotel. Bandung: CV. Alfabeta. Dimyati. (2002). Basic Knowledge of Hospitality. Jakarta: CV. Subscribe Deviri. Kotler, Philip. (2003). Marketing Management. 11th Edition. New Jersey: Prentice Hall, Inc.

Kotler, Philip and Gary Armstrong (2012). Principle of Marketing, Fourteenth Edition.

Pearson Education Limited, England.

Like Dawn. (2008). Marketing Management. Yogyakarta: PT. Graha Science. Lovelock, Christopher and Lauren Wright (2002). Principles of Service Marketing and 
Management. Second Edition. Pearson Education International, Inc. Prentice Hall.

Lupiyoadi, Creep and A. Hamdani. (2011). Marketing Management Services. Issue Two.

Four Salemba, Jakarta.

Nana Tasunar. 2006. Quality of Service Strategies to Create Satisfaction Fish Landing Base (PPI) Morodemak. Indonesian Journal of Marketing Science, Vol. V, No. May 1, 2006, p. 41-62.

Nugroho Agus. (2005). Strategies Strategies: Selecting Statistical Methods Research with

SPSS. Yogyakarta: Andi.

Nur Nasution, M. (2004). Research Customer Satisfaction Levels As Predictors Of Customer

Loyalty Mobile Provider. Media Business and Management Research, Volume 2, Number 1.

Nur Nasution, M. (2005). Integrated Quality Management (Total Quality Management).

Indonesia: Ghalia.

Parasuraman, Valarie A. and Berry. (2002). Delivering Service Quality. New York: Mc

Milan.

Rumekso. (2001). Housekeeping Hotel. Yogyakarta: Andi.

Sekaran. (2006). Research Methodology for Business. (Issue 4) .Jakarta: Salemba Four.

Sugiyono. (2006). Business Research Methods. Bandung: CV. Alfabeta.

Sugiyono. (2012). Quantitative Research Methods, Qualitative and R \& D. Bandung:

Alfabeta.

Sugiyono. (2006). Engineering Research. Yogyakarta: Pines.

Supranto, J. (2001). Measuring Customer Satisfaction Levels To Increase Market Share.

Jakarta: Rineka Reserved.

Tjiptono, Fandy. (2005). Service, Quality, and Satisfaction. Yogyakarta: Andi Offset ..

Tjiptono, Fandy. (2005). Principles of Total Quality Service. Yogyakarta: Andi. Wisnalmawati. (2005). Influence Perception of Service Quality Dimensions Against Repeat

Purchase Intentions. Journal of Economics and Business, No. 3 Volume 10, 2005, p. 153-165.

Zeithaml L. Berry, Valarie A, and A. Parasuraman. (1996). The Behavioral Consequences of

Service Quality, Nature and Determinants of Customer Expectations of Service. "Journal of Marketing". Google Translate for Business:Translator ToolkitWebsite TranslatorGlobal Market Finderdd 